\title{
Teachers' Professional Development to Enhance ELT: Needs Analysis for Developing Teacher Training Program in an EFL Context
}

Janak Singh Negi

\begin{abstract}
Developing any new teacher training program for Teachers' Professional Development (TPD) should start from where the teachers are and what they actually need, which is very essential to bring out innovation and improvement in the field of ELT. The present study represents teachers' voices from Far Western and Mid-Western part of Nepal based on the survey data collected from EFL teachers. The researcher reached to the conclusion that teachers should be trained and given opportunities on how to put the existing knowledge in to practice according to the learning context, needs and available resources creating their own context specific methodology keeping oneself up to date with global practices including the integration of ICT in the field of ELT.
\end{abstract}

Key words: Teachers' professional development, ELT, teacher training

\section{Introduction}

There is a growing demand of English Language Teaching (ELT) worldwide. Hence, experts in the field of ELT are constantly developing new theories, methods and techniques, which have gone through a number of radical changes during the last few decades and still is in constant movement and change to improve the status of English language teaching and learning. Teachers are the key personalities to bring out these new innovations and improvement in this field. Moreover, in order to grow professionally and to adopt these innovative practices, teachers need to strengthen their professional expertise through the professional development opportunities.

\section{Professional development}

Professional development is the process by which alone and with others, teachers review, renew and extend their commitment as change agents to the moral purpose of teaching, and by which they acquire and develop critically the knowledge, skills and emotional intelligence essential to good professional thinking, planning and practice with children, young people and colleague throughout each phase of their lives (Day, 1999) to achieve the objectives of the teaching and learning process successfully (Shoquair \& Shaaban, 2013). It has not fixed route and real end rather it is a lifelong process (Rodrigues, 2005 as cited in Shoquair \& Shaaban, 2013) in which 
teachers engage voluntarily to learn and adjust their teaching to the learning needs of their students (Diaz- Maggioli, 2003) and to keep their skills and career fresh (Alfaki, 2014). According to Blandford (2000) 'professional development refers to the planned activities practiced both within and outside schools to develop the professional knowledge, skills, attitudes, and professional staff in schools' (p. 6), in order to educate their learner more effectively and affirms the knowledge, experience and intuitive judgment they have cultivated during their career (Rodriguez \& Mckay, 2010) to adjust their teaching to their students' needs(DiazMaggioli 2003). Furthermore, Feiman Nemser (2001) talks about two aspects of professional development, First, he mentions the actual learning opportunities in which teachers engage in their time and place, content and pedagogy, sponsorship and purpose; and the learning that occurs from participating such activities; second, in the transformation in teachers knowledge, understandings, skills and commitments in what they do, want and able to do in their individual practice as well as their shared responsibilities.

In nutshell, we can say that 'professional development is a multi-faced life long experience, which can take place inside or outside the work place' (Hayes, 2014, p.5) undertaken to improve an individual's ability (Alfaki, 2014) to refresh their enthusiasm for teaching (Rodriguez \& Mckay, 2010). At last we can say that professional development is the process of learning and learning again to apply new knowledge and skills that will improve their performance on the job. It is not limited to formal learning contexts only but also occurs in informal contexts such as discussing among teachers, independent reading, conducting action research, reviewing colleague's work or other learning from the teaching staffs and students including reflecting on their own classroom teaching.

\section{Professional development and innovative practices in ELT}

Past language teaching was mainly focused on the era of method. It was after the genesis of direct method in the 1920 which generally makes the beginning of this method era (Richards and Rodgers, 2001).During those days, for some policy makers and reformers, improving in teaching is mainly a matter of developing better teaching method (El-Fiki, 2012, p.3) as a result; language teaching pendulum has swung away from grammar translation to direct method then alternative methods (Richards and Rodgers, 2003) such as audio lingual, total physical response, communicative language teaching, to name only a few. These methods waxed and waned in popularity (Brown, 2001) as the changing winds and shifting sands (Marckwardt, 1972). Such shifts from one method to another only provide ample inferential evidence of lack of success (Sheen, 1994). As a result, ELT professionals realized that:

There never was and probably never will be a method for all and the focus in recent years has been on the development of classroom tasks and activities consonant with what we know about second language acquisition and which are also in keeping with the dynamics of the classroom itself. (Nunan, 1991, p. 228)

Furthermore, 'one method that works well with a certain group of students may not be suitable for others' (Dincay, 2011, p.58). However, in course of finding better way of teaching ELT practitioners have made 
the shift from teacher to learner (Freeman and Richard, 1993) from method based top down to teacher based bottom up approaches (Freeman and Richards, 1993) and holistic teaching (Myers and Hilliard, 1997) to integrated skill based approach (Oxford, 2001).

At last, It was at the end of 1980s, (Long,1989 as cited in Fashim and Pishghadam, 2009) came up with an ' anti- methods' view of language teaching methodology and claimed that methods do not matter because they do not exist' (p. 39), which is also supported by (Parbhu,1990) who claimed that there is no perfect method. So, the era of method is over (Brown, 1994b). This epoch was directly linked to the post method era: purchasing goods in super market according to your needs and money on your pocket! As a result, ELT professionals use a single or mixture of multiple ELT methods and techniques according to their needs/ demands, level of their students, available resources and so on. Some expert named it eclectic method and recently others e.g. Brown (2002), Kumarivadivelau (2001, 2006), Liu (2004), Akbari (2008) to name only a few advocate for post method pedagogy. It means there is not a single or perfect method for ELT rather we have to make our teaching perfect using various methods and techniques according to our own classroom context. Furthermore, these shifts and trends in instructional practices are regularly being changed and updated, which indicates the need of constant professional development opportunities for teachers

In recent years, development in ICT has expanded the horizons for teachers to learn, share and network (Hayes, 2014). New technologies like internet, twitter, you tube, skype blogs, mobile phones to name only a few have added not only stimulus but also learners' engagement and interactivity within the classroom, on the way to school and at home, which has also transformed writing notes on blackboard to using a smart board or from audio cassette player to using multimedia technology. Moreover, todays teach-savvy students have a world of resources and information at their finger tips (Eaton, 2010) and use various kinds of technological devices that give language students the sense of freedom, motivation and encouragement (Genc-Ilter, 2009 as cited in Traone and Kyei-Blankson, 2011). Furthermore, various teaching websites provide training through webinars, share videos of classrooms and resources and encourage sharing among teachers across the globe through its face book and twitter comments (Hayes, 2014) as well. It means, there are many online recourses, where students can practice and learn language. In another words, web based learning provides new possibilities and trends for teachers and learners.

In conclusion, we can say that on the one hand, 'teaching is full of contingencies and it is also true that there is often a gap between our intentions and actions and that many decisions are outside the control of teachers' (Dincay 2010, p.59) on the other hand, successful teaching and teacher development cannot be managed by others rather it is the teacher who decides which activities and/or resources should be used and for how long it should last for his/her own development (Turhan \& Arikan, 2009). There is an increasing demand worldwide for such competent teachers but there may not be sufficient professional teachers and they need to be professionalized and the current need is to develop teachers' professional expertise which can be enhanced through teacher's professional development.

$42 \quad$ Journal of NELTA, Vol 21 No. 1-2, $\quad$ December 2016 


\section{Review of related literature}

Some of the recently carried out research in this field include Harwell (2003) who carried out the research entitled teachers' professional development: it's not an event; it's a process which refocuses on the importance of teachers' professional development in teachers' classroom behavior to improve the students' performance. Similarly,Moncada (2007) carried out the research on professional development of EFL teachers in Colombia: between colonial and local practices, the study suggested the need for more post method approaches, for locally produced knowledge to be recognized, and for the collaborative work of policy makers and national scholars to generate teacher development programs more adequate to our reality. In the same way, Kusumoto (2008) reached at the finding that adequate and appropriate teacher training is the key to any success in language education. In the field of TPD Shoquair \& Shaaban (2013) carried out the research on strategies of professional development for EFL and technology teachers. The study revealed that conducting action research continually, using social networks (twitter, facebook and others) in exchanging viewpoints and experiences and participating in educational e-forums, were the most common strategies because they recorded high percentages of teachers' responses. Furthermore, Ahmed's (2014) study indicated that the trainers want training from native speakers to develop their listening skills, knowledge and attitude towards trainees. The same year Alfaki (2014), Khany \& Darabi (2014), carried out researches on ELT and TPD. Alfaki reached at the conclusion that teachers have their own role to play in their professional development along with the role played with the government; and for professional development; both experience and reflective teaching are required, sharing experience and ideas between colleagues gives teachers a feeling of community and belonging. The study by Khany and Darabi showed that principlesbased and post method pedagogy were not highly applied in teachers' performance in the classroom. Furthermore, Ortactepe \& Akyel (2015) highlighted the importance of awareness-raising activities for professional development programs as well as the need for multiple instruments to analyze the extent to which teachers' 'selfreported beliefs and practices concur with their observed teaching practice'. The present study attempts to investigate the training needs of teachers in an EFL context in Nepal.

\section{Objectives}

The objectives of the present study were as follows:

a) To investigate the training needs of teachers in an EFL context.

b) To determine the training needs of the teachers to be incorporated in the training package.

\section{Significance of the study}

Teacher training and professional development programs which depend on knowledge transmission models may not be effective in bringing about the desired change (Adey \& Hewitt, 2004). So, the core of teacher education and professional development must centre on the activity of teaching itself, the teacher who does it, and the context in which it is done (Freeman and Johnson, 1998, Richards, 2008) and teachers voices should be heard clearly (Hargreaves, 1994) because they need wide variety of ongoing educational opportunities to improve their teaching skills. This study places the teachers in centre and tries to 
investigate the training needs of teachers in an EFL context. I suppose, this study will provide teacher trainers with a wider repertoire of responses to be considered as they re-evaluate and reflect on their own training practices.

\section{Methodology}

It was a survey. This study was carried out on 120 teachers. Those teachers were purposely selected from 60 different government schools of Baitadi and Surkhet districts of Far Western and Mid Western part of Nepal respectively. They were teaching English in grade 8-10 with at least five years of teaching experience and previous training experience. Out of 120 teachers 112 teachers returned the questionnaire.

For the collection of the data, questionnaire was designed to find out the teachers' beliefs, skills, practices and problems in their instructional practices to determine the training needs. Questionnaire consisted of the components of current instructional practices and issues in ELT such as 'integration of ICT in ELT, managing large classroom, students learning practices, assessing students, error correction and feedback including the medium of instruction, lesson planning and time management, action research and reflective practices as well as teacher training and post training support'. The questionnaire consisted of Forty-One closed ended questions which required the informants to indicate his/her response by putting the tick mark on one of the option given. Collected data was analyzed using the simple mathematical tool percentage.

\section{The result and description}

Data obtained from the teachers was analyzed and interpreted as follows:

\section{Integration of ICT in ELT}

Most of the teachers (72.32\%) believed that computers and its applications can be very useful for language teaching and learning but they $(64.28 \%)$ didn't know what kind of language teaching resources could be found on internet. Furthermore, teachers $(62.5 \%)$ were not familiar with technology. Moreover, large number $(84.82 \%)$ of the teachers did not to know how to use ICT to improve students' learning. It showed thatintegration of ICT in ELT could be helpful for teachers' instructional practices but the bitter reality was that large number of teachers was neither familiar with ICT nor with its application in the field of ELT. It indicates the need of training on ICT and its integration in ELT. However, most of the $(91.96 \%)$ teachers did not have computers at their home, but the data showed that they $(60.71 \%)$ had internet access at least on their mobile phone. So, it is true to assume that they could use their mobile phone as a means of finding and sharing internet resources to enhance their professional expertise, which indicates the need of launching mobile Apps to enhance the qualities of ELT practices, especially in the remote and resource poor areas of the country where computers are not available at schools.

\section{Managing large classroom}

The data showed that most of the (62.5\%) teachers had more than 40 students in their classroom and they $(98.92 \%)$ had to face a lot of difficulties in teaching such a large classroom, As the data revealed, large numbers of teachers need classroom management skills as well as designing multi-level teaching learning activities to handle the large classroom. Furthermore, $50 \%$ of the teachers agreed that students learn collaboratively working in groups and pairs; however, they (64.28\%) control the classroom and did not practice 
interactive methodology because they $(60.71 \%)$ thought that interaction among students in the classroom would disturb the other classes nearby. It means teachers had good sense of the positive aspects of collaborative learning; however, they were not skilled in managing students into pair/ group and in the proper implication of interactive teaching methodology.

\section{Students' learning practice}

Teachers (44.64\%) agreed that students were not serious and pay much attention in their learning rather they gave much emphasis on solving old questions (model questions) and memorizing the same to pass the exam. As the data revealed, learning was considered as equivalent to pass the exam or grading up which was based on memorization of the fixed set of answers. Since the students did not pay much attention to their study it might be due to the lack of motivation. It indicates the needs of developing techniques and skills to motivate students in learning. It means teachers need skills to motivate their students in learning and teach them 'how to learn'.

\section{Assessing students, error correction and feedback}

Analysis of the data showed that teachers (58.03\%) were familiar with common students' mistakes and errors, however, large number $(76.79 \%)$ of teachers were not confident in correcting students' mistakes and errors. Furthermore, they $(48.21 \%)$ also knew how to evaluate students' language performance in a classroom. For example, they $(55.35 \%)$ agreed that assessment for learning is an effective tool for improving teaching and learning. However, they $(77.68 \%)$ did not practice these pedagogical skills very often in the classroom practically. It indicates that teachers possessed some skills related to student assessment, error correction and feedback but they did not practice these skills in their instructional practices. It signals the need of training on how to put their professional skills in to practice. Moreover, large number of teacher $(73.21 \%)$ did not ask Instruction Checking Questions (ICQ) and Concept Checking Questions (CCQ) to their students because they $(73.21 \%$ ) did not have any idea about it, but it is general truth that students cannot understand unless they get the concept and they cannot complete the task unless they understand the instruction clearly, but most of the teachers did not have the idea about ICQ and CCQ. It implies that teachers need training on asking ICQs and CCQs.

\section{Medium of instruction}

Teachers $(60.71 \%)$ had the opinion that English should only be taught through English but most of the time they (71.42\%) use students' mother tongue to make students understand the text. It indicates that either teacher used too difficult language with their students in the classroom to understand or they did not follow the steps of teaching i.e. teaching pre vocabulary or setting the scene etc. It signals that teachers need to develop their skills to use simple 'classroom language' and to consider the stages of teaching language skills according to their students' language level and background.

\section{Lesson planning and time management}

Teachers (49.10\%) agreed that they were well skilled in preparing lesson plan and designing teaching learning materials however, they $(49.10 \%)$ did not have time to prepare lesson plan. Furthermore, they $(62.5 \%)$ could not manage time within one period (35 to 45 minutes) for effective teaching. It means, either teachers did not use their skills or they had to spend hours 
to prepare a single lesson plan, though the interpretation is not straightforward, it indicates the need to strengthen teachers' skills in designing lesson plan practically in the real context.

\section{Action research and reflective practice}

The result showed that only few $(16.07 \%)$ teachers conducted the action research. However, large number $(54.46 \%)$ of the teacher did not have the idea regarding action research. Furthermore, they $(87.5 \%)$ did not carry out the self-reflection and share their (58.04 \% of the teacher) teaching experiences among colleagues. However, they $(66.07 \%)$ agreed that they had to face many problems in the classroom. All of which could not be solved in the training. The data showed that only few teachers conducted the action research and carried out self-reflection but the large number of teachers did not have even the idea of conducting the action research and practicing self-reflection. However, conducting action research and selfreflection are the key professional practices to improve teaching and bring out new innovation in the field of ELT. So, there is drastic need to train teachers on how to conduct action research and reflect on their own teaching to invent and practice their own context specific teaching methodology.

\section{Teacher training and post- training support}

Most $(64.28 \%)$ of the teachers agreed that they had learnt many teaching skills from the teacher training. However, they $(75.89 \%)$ need guidance and feedback from the experienced teachers and trainers to put the theories into practice during classroom teaching, furthermore, they (75\%) agreed that feedback from experienced teachers and trainers plays an important role in successful language teaching and learning. Since large portion of the teachers need guidance and feedback, it implies that they were not confident in teaching and need further support. It signals the need to raise the confidence level of the teachers through mentoring and training.

\section{Major findings}

Although teachers gain sufficient theoretical input in training programs, they have difficulties to put it in to practice. So, there is drastic need for training on " professional skills management strategy including the integration of ICT in the field of ELT'. Besides, conducting action research is one of the key features that facilitates and hones teachers' expertise in their professional repertoire because it brings both action and reflection together in the pursuit of practical solutions which are directly related to the classroom teaching and brings changes in the way teachers perceive their teaching and improves teaching practices. (Negi, 2016). Action research also encourages teachers to collect and examine data about their teaching for critical reflection and improvement in their teaching which encourages teachers to become continuous learners with in their classroom and schools (Richards and Lockhart 1994, Mills, 2011 as cited in Negi, 2016). However, most of the teachers lack practical skills on conducting action research and reflective practice. So, they need training on conducting action research as well as practicing context specific teaching strategies including planning their lessons accordingly. Furthermore, most of the teachers are facing problems in large classrooms and are in sever need of training on designing multilevel activities, effective techniques to facilitate assessment for learning including asking CCQs/ICQs as well as the ways of giving adequate feedback to their students. 


\section{Recommendations}

There is an extreme need to integrate ICT in training module. Although, most of the teachers do not have computer at their home they have internet access on their mobile phone. So, mobile teach app should be launched for teachers and students to enhance their teaching and learning. In addition to the integration of ICT, effective strategies for teaching ELT in large classroom should be emphasized in TPD training programs. Most of the teachers have difficulties to apply the theoretical knowledge in their actual classroom. So, teachers' professional skills management scheme should be emphasized practically to put the theory into practice e.g. preparing lesson plan, effective use of available resources, increasing STT (Student Talking Time), motivating students in learning, checking students understanding i.e. asking ICQ and CCQs to name only a few.

During the training, it would be better to avoid giving too much emphasis on teaching, however it would be far better to focus on students' learning, conducting action research, sharing experiences, reflective practices and collaborative learning among teachers as well as teaching practices; consequently, teachers will generate theories themselves. Furthermore, it would also be better to focus more on what is happening in their (teachers') own classroom context, detect the problems and find the appropriate solutions. Moreover, training should not only be completed in the well facilitated training hall among teachers which is quite different from the real classroom context; conversely, trainers should follow up and help the teachers in their classroom while teaching in the real context.

\section{Conclusion}

Teachers' professional development is essential for better learning output. Most of the teachers are trained and they have gained sufficient knowledge on ELT theory including new innovation in ELT but the bitter reality is that most of the teachers cannot put their theoretical knowledge in to practice. Most of the training program still give emphasis on introducing new techniques and innovations in ELT, but I reach the conclusion that teachers should be trained and given opportunities on how to put the existing knowledge in to practice according to the learning context, needs and available resources creating their own context specific methodology keeping oneself up to date with global practices in the field of ELT. The development of new training program should start from where the teachers are. And providing proper kind of follow up support and feedback is equally essential to help teachers to put theory in to practice.

\section{References}

Adey, P., \& Hewitt, G. (2004). The professional development of teachers: Practice and theory. London: Kluwer Academic.

Ahmed, R. (2014). Effects of BRAC training on secondary school teacher trainers. An unpublished masters' thesis, BRAC University, Dhaka. Retrieved from http://dspace.bracu.ac.bd:8080/ xmlui/bitstream/handle/10361/ 3283/13177006.pdf;sequence $=1$

Akbari, R. (2008). Postmethod discourse and practice. TESOL Querterly, 42(4), 641-652.

Alfaki, I.M. (2014). Professional development in English language 
teaching: A teachers' view. British Journal of Education, 2(7), 32-49

Blandford, S. (2000). Managing professional development in schools. New York: Routledge.

Brown, H.D. (1994b) Teaching by principles: Interactive language teaching methodology. NY: Printice- Hall.

Brown, H.D. (2001). Teaching by principles: An interactive approach to language pedagogy. New York: Longman.

Brown, H.D. (2002). English language teaching in the post-method era: Towards better diagnosis, treatment and Assessment. In J. Richards \& W.A. Renandya (Eds.) Methodology in language teaching: An anthology of current practice. Cambridge: Cambridge University Press.

Day, C. (1999). Developing teachers: The challenges of lifelong learning. London: Falmer press.

Diaz-maggioli, G.H. (2003). Professional development for language teachers. Retrieved from http:// www.cal.org/ resources/digest/0009diaz.html.

Dincay, T. (2010). A quick chronological review of the ELT methods along with their techniques and principles: Choosing eclecticism from among language teaching methods Retrieved from http:/ / dergiler.ankara.edu.tr/ dergiler/27/1603/17283.pdf

Eaton, S. E. (2010). Global trends in language learning in the twenty-first century. Calgary: Onate press.

El-Fiki, H. (2012). Teaching English as a foreign language and using English as a medium of instruction in Egypt: Teachers' perceptions of teaching approaches and source of change. An unpublished Ph.D. Dissertation, Graduate department of curriculum, teaching and learning, Ontario institute for studies in education. University of Toronto. Retrieved from: https:// tspace.library.utoronto.ca/bitstream/ $1807 / 32705 / 3 / \mathrm{E} 1$ Fiki_Hana_A_201206_PhD_thesis.pdf

Fashim, M., \& Pishghadam, R. (2009). Post modernism and English language teaching. IJALS, 1(2), 27-54.

Feiman-Nemser, S. (2001). From preparation to practice: Designing a continuum to strengthen and sustain teaching. Teachers College Record, 103 (6), 1037-1055.

Freeman, D., \& Johnson, K.E. (1998). Conceptualizing the knowledge-base of language teacher education. TESOL Quarterly, 32, 397-417.

Freeman, D., \& Richards, J.C. (1993). Conceptions of teaching and the education of second language teachers. TESOL Quarterly,27 (2), 193-116.

Freeman, D., \& Richards, J.C. (1993). Conceptions of teaching and the education of second language teachers. TESOL Quarterly, 27(2), 193-216.

Hargreaves, A. (1994). Changing teachers, changing times. London: Cassell.

Hayes, D. (Eds.). (2014). Innovation in the continuing professional development of English language teachers. British Council. Retrieved from: https:// englishagenda.britishcouncil.org/ sites/ec/files/E168\%20Innovations \%20in\%20CPD_FINAL\%20V2\%20web.pdf 
Khany, R. \& Darabi, R. (2014). ELT in Iran: Reflection of the principles-based and post method pedagogy in language teaching. Procedia- social and behavioral sciences, 98, 908-916.

Kumaravadivelu, B. (2001). Toward postmethod pedagogy, TESOL Querterly, 35(4), 537-560.

Kumarivadivelu, B. (2006). TESOL methods: Changing tracks, changing trends, TESOL Querterly, 40, (1), 39-81.

Kusumoto, Y. (2008). Needs analysis: Developing a teacher training program for elementary school homeroom teaching in Japan. Second Language Studies, 26 (2), 1-44.

Marckwardt, A. (1972). Chinging winds and shifting sands. MST English Quarterly, 21, 3-11.

Moncada, A.G. (2007). Professional development of EFL teachers in Colombia: Between colonial and local practices. Retrieved from http:// www.redalyc.org/pdf / 2550 / 255020488012.pdf .

Negi, J.S. (2016). Improving teaching through action research; perceptions, practices and problems (3Ps): Voices from secondary level teachers in an EFL context. ELT Voices, 6 (4), 18-30.

Nunan, D. (1991). Language teaching methodology: A textbook for teachers. New York: Prentice- Hall.

Ortactepe, D. \& Akyel, A. (2015). The effects of a professional development program on English as a foreign language teachers' efficacy and classroom practice. TESOL Journal, 6.(4), 680- 706.
Oxford, R. (2001). Integrated skills in the ESL/EFL classroom. ESL Magazine, $4(1), 18-20$

Parbhu, N.S. (1990). There is no best method- why?,TESOL Querterly, 24(2), 161-176.

Richards, J. (2008). Second language education today. RELC Journal, 39 (158), 158- 178.

Richards, J.C. \& Rodgers, Th.S. (2003). Approaches and methods in language teaching ( $\left.2^{\text {nd }} e d.\right)$. Cambridge: Cambridge university press.

Richards, J.C., \& Rodgers, T. (2001). Approaches and methods in language teaching ( $\left.2^{\text {nd }} e d.\right)$. Cambridge: Cambridge University Press.

Rodrigues, A.G. \& Mckay, S. (2010). Professional development for experienced teachers working with adult English language learners. Retrieved From: http://www.cal.org/ c a e l a n e t w o r k / p d f s / ExpTeachersFinalWeb.pdf

Sheen, R. (1994). A critical analysis of the advocacy of the task-based syllabus. TESOL Quarterly, 28 (1), 127-153.

Shoquair, M.S.A. \& Shaaban, S.S.A. (2013). Strategies of professional development for EFL and technology teachers. Educational Journal, 2(6), 249-255.

Traone, M., \& Kyei-Blankson, L. (2011). Using literature and multiple technologies in ESL instruction. Journal of Language Teaching and Research, 2(3), 561-568.

Turhan, I.E., \& Arikan, A. (2009). English language teacher development with 
and without a teacher trainer: ELT instructors' perceptions. E-journal of New World Sciences Academic, 4(2). Retrieved from: http:// www.newwsa.com/download/ gecici_makale_dosyalari/NWSA1747-985-10.pdf

The author: Mr. Janak Singh Negi is teaching faculty Asst. Professor at
Manilek Campus, affiliated to Tribhuvan University, Nepal. He has been involved in teaching and teacher training for last ten years. Mr. Negi is also a life member of NELTA and has served as a teacher trainer. He is particularly interested in ICTs for teacher development and young learners.

\section{Appendix ' $A$ '}

\section{Needs of Training in an EFL context}

\begin{tabular}{|c|c|c|c|c|c|}
\hline S.N. & Scenario & Agree & NAND* & Disagree & No Idea \\
\hline \multicolumn{6}{|c|}{ Integration of ICT in ELT } \\
\hline 1. & $\begin{array}{l}\text { Computers and its application can be very useful for } \\
\text { language teaching and learning. }\end{array}$ & $72.32 \%$ & $15.17 \%$ & $0 \%$ & $12.5 \%$ \\
\hline 2. & $\begin{array}{l}\text { I want to learn about the use of ICT (Information } \\
\text { and Communication Technology) in English } \\
\text { language teaching. }\end{array}$ & $80.35 \%$ & $13.39 \%$ & $0 \%$ & $6.25 \%$ \\
\hline 3. & I am quite familiar with technology. & $25.89 \%$ & $11.60 \%$ & $62.2 \%$ & $0 \%$ \\
\hline 4. & $\begin{array}{l}\text { It is said that internet contains teaching and learning } \\
\text { resources. }\end{array}$ & $73.21 \%$ & $17.85 \%$ & $0 \%$ & $8.92 \%$ \\
\hline 5. & $\begin{array}{l}\text { I know what kind of language teaching resources } \\
\text { can be found on internet. }\end{array}$ & $11.60 \%$ & $16.07 \%$ & $64.28 \%$ & $8.03 \%$ \\
\hline 6. & I can have internet access on my mobile phone. & $60.71 \%$ & $0 \%$ & $39.28 \%$ & $0 \%$ \\
\hline 7. & $\begin{array}{l}\text { I know how to use ICT to improve my students' } \\
\text { learning. }\end{array}$ & $10.71 \%$ & $4.46 \%$ & $84.82 \%$ & $0 \%$ \\
\hline 8. & $\begin{array}{l}\text { I have both computer and internet access at my } \\
\text { home. }\end{array}$ & $8.83 \%$ & $0 \%$ & $91.96 \%$ & $0 \%$ \\
\hline \multicolumn{6}{|c|}{ Managing Large Classroom } \\
\hline 9. & $\begin{array}{l}\text { I have to teach many (more than } 40 \text { ) students in my } \\
\text { classroom. }\end{array}$ & $62.25 \%$ & $0 \%$ & $37.5 \%$ & $0 \%$ \\
\hline 10. & $\begin{array}{l}\text { I face a lot of difficulties in teaching such a large } \\
\text { classroom. }\end{array}$ & $58.92 \%$ & $16.96 \%$ & $24.10 \%$ & $0 \%$ \\
\hline 11. & I can easily control my students in the classroom. & $64.28 \%$ & $26.78 \%$ & $8.92 \%$ & $0 \%$ \\
\hline 12. & $\begin{array}{l}\text { Students do not interact with each other in my } \\
\text { classroom. }\end{array}$ & $58.03 \%$ & $26.78 \%$ & $15.17 \%$ & $0 \%$ \\
\hline 13. & $\begin{array}{l}\text { Interaction among students in the classroom } \\
\text { disturbs the other classes nearby. }\end{array}$ & $60.71 \%$ & $17.85 \%$ & $14.28 \%$ & $\mathrm{Uu}$ \\
\hline 14. & My students learn working in groups and pairs. & $50 \%$ & $16.07 \%$ & $22.32 \%$ & $11.60 \%$ \\
\hline 15. & I have difficulties in classroom management. & $56.25 \%$ & $23.21 \%$ & $16.96 \%$ & $3.57 \%$ \\
\hline \multicolumn{6}{|c|}{ Students' Learning Practices } \\
\hline 16. & $\begin{array}{l}\text { Students give much emphasis on solving old } \\
\text { questions (model questions). }\end{array}$ & $42.85 \%$ & $53.57 \%$ & $3.57 \%$ & $0 \%$ \\
\hline 17. & Students only memorize the answer to pass the & $44.64 \%$ & $28.57 \%$ & $25 \%$ & $8.92 \%$ \\
\hline
\end{tabular}




\begin{tabular}{|c|c|c|c|c|c|}
\hline & exam. & & & & \\
\hline 18. & Students are very serious in their learning. & $17.85 \%$ & $25.89 \%$ & $44.67 \%$ & $11.60 \%$ \\
\hline \multicolumn{6}{|c|}{ Assessing Students, Error correction and Feedback } \\
\hline 19. & $\begin{array}{l}\text { I know how to access/evaluate students' language } \\
\text { performance in a classroom. }\end{array}$ & $73.21 \%$ & $26.78 \%$ & $0 \%$ & $0 \%$ \\
\hline 20. & $\begin{array}{l}\text { I can access/evaluate students' achievement in } \\
\text { various ways. }\end{array}$ & $48.21 \%$ & $43.75 \%$ & $8.03 \%$ & $0 \%$ \\
\hline 21. & $\begin{array}{l}\text { Assessment for learning is an effective tool for } \\
\text { improving teaching and learning. }\end{array}$ & $55.35 \%$ & $14.28 \%$ & $1.78 \%$ & $28.57 \%$ \\
\hline 22. & $\begin{array}{l}\text { I am familiar with common students' mistake and } \\
\text { errors. }\end{array}$ & $50.03 \%$ & $26.78 \%$ & $4.46 \%$ & $10.71 \%$ \\
\hline 23. & $\begin{array}{l}\text { I am confident in correcting students' mistake and } \\
\text { errors. }\end{array}$ & $23.21 \%$ & $41.96 \%$ & $31.25 \%$ & $3.57 \%$ \\
\hline 24. & Making mistake is harmful in language learning. & $26.78 \%$ & $0 \%$ & $42.85 \%$ & $30.35 \%$ \\
\hline 25. & $\begin{array}{l}\text { I ask Instruction Checking Questions and Concept } \\
\text { Checking Questions (ICQ and CCQ) to my students. }\end{array}$ & $7.14 \%$ & $4.46 \%$ & $15.17 \%$ & $73.21 \%$ \\
\hline 26. & $\begin{array}{l}\text { I often practice the activities mentioned in the } \\
\text { statements, } 19,20,23 \text {, and } 24 \text {. }\end{array}$ & $22.32 \%$ & $17.85 \%$ & $49.10 \%$ & $10.71 \%$ \\
\hline
\end{tabular}

The Medium of Instruction

\begin{tabular}{|l|l|l|l|l|l} 
27. & $\begin{array}{l}\text { I use students' mother tongue to make my students } \\
\text { understand the text. }\end{array}$ & $71.42 \%$ & $20.53 \%$ & $8.03 \%$ & $0 \%$ \\
\hline 28. & English should only be taught through English. & $60.71 \%$ & $17.85 \%$ & $16.07 \%$ & $5.35 \%$ \\
\hline
\end{tabular}

Lesson Planning and Time Management

\begin{tabular}{|l|l|l|l|l|l|}
\hline 29. & I am well skilled in lesson planning. & $49.10 \%$ & $33.03 \%$ & $12.5 \%$ & $5.35 \%$ \\
\hline 30. & I have enough time to prepare lesson plan & $18.75 \%$ & $12.5 \%$ & $68.75 \%$ & $0 \%$ \\
\hline 31. & $\begin{array}{l}35-45 \text { minutes' time for per period is inadequate for } \\
\text { teaching English effectively. }\end{array}$ & $62.5 \%$ & $17.85 \%$ & $19.64 \%$ & $0 \%$ \\
\hline
\end{tabular}

Action Research and Self Reflective Practice

\begin{tabular}{|l|l|l|l|l|l|}
\hline 32. & $\begin{array}{l}\text { Self-reflective practice is quite helpful to improve } \\
\text { teaching and learning. }\end{array}$ & $12.5 \%$ & $14.28 \%$ & $10.71 \%$ & $62.25 \%$ \\
\hline 33. & $\begin{array}{l}\text { I have conducted many action researches to } \\
\text { improve my teaching }\end{array}$ & $16.07 \%$ & $6.25 \%$ & $23.21 \%$ & $54.46 \%$ \\
\hline 34. & $\begin{array}{l}\text { Teachers Professional Development Training } \\
\text { (TPDT) prepares teachers to use research based } \\
\text { teaching strategies based on their own context. }\end{array}$ & $2.67 \%$ & $23.21 \%$ & $55.35 \%$ & $18.75 \%$ \\
\hline 35. & $\begin{array}{l}\text { I face many problems while teaching in the } \\
\text { classroom. }\end{array}$ & $66.07 \%$ & $14.28 \%$ & $19.64 \%$ & $0 \%$ \\
\hline 36. & $\begin{array}{l}\text { All of my classroom problems are solved in the } \\
\text { training. }\end{array}$ & $13.39 \%$ & $15.17 \%$ & $71.42 \%$ & $0 \%$ \\
\hline 37. & I share my teaching experiences with my colleagues. & $41.96 \%$ & $33.92 \%$ & $21.42 \%$ & $2.67 \%$ \\
\hline Teacher Training and Post Training Support & $\begin{array}{l}\text { I have learnt many teaching skills from the teacher } \\
\text { trainings. }\end{array}$ & $64.28 \%$ & $20.53 \%$ & $15.17 \%$ & $0 \%$ \\
\hline 38. & $\begin{array}{l}\text { It is difficult to implement new methods and } \\
\text { techniques learnt in the training. }\end{array}$ & $62.5 \%$ & $19.96 \%$ & $20.53 \%$ & $0 \%$ \\
\hline 40. & $\begin{array}{l}\text { I want regular mentoring from the experienced } \\
\text { teachers and trainers. }\end{array}$ & $75.89 \%$ & $10.71 \%$ & $12.5 \%$ & $0.89 \%$ \\
\hline 41. & $\begin{array}{l}\text { Feedback from experienced teachers plays an } \\
\text { important role in successful language teaching and } \\
\text { learning. }\end{array}$ & $75 \%$ & $10.71 \%$ & $13.39 \%$ & $0.89 \%$ \\
\hline
\end{tabular}




\begin{tabular}{|c|c|c|c|c|c|}
\hline S.N. & Scenario & Agree & NAND* & Disagree & No Idea \\
\hline \multicolumn{6}{|c|}{ Integration of ICT in ELT } \\
\hline 1. & $\begin{array}{l}\text { Computers and its application can be very useful for } \\
\text { language teaching and learning. }\end{array}$ & $72.32 \%$ & $15.17 \%$ & $0 \%$ & $12.5 \%$ \\
\hline 2. & $\begin{array}{l}\text { I want to learn about the use of ICT (Information and } \\
\text { Communication Technology) in English language } \\
\text { teaching. }\end{array}$ & $80.35 \%$ & $13.39 \%$ & $0 \%$ & $6.25 \%$ \\
\hline 3. & I am quite familiar with technology. & $25.89 \%$ & $11.60 \%$ & $62.2 \%$ & $0 \%$ \\
\hline 4. & $\begin{array}{l}\text { It is said that internet contains teaching and learning } \\
\text { resources. }\end{array}$ & $73.21 \%$ & $17.85 \%$ & $0 \%$ & $8.92 \%$ \\
\hline 5. & $\begin{array}{l}\text { I know what kind of language teaching resources can } \\
\text { be found on internet. }\end{array}$ & $11.60 \%$ & $16.07 \%$ & $64.28 \%$ & $8.03 \%$ \\
\hline 6. & I can have internet access on my mobile phone. & $60.71 \%$ & $0 \%$ & $39.28 \%$ & $0 \%$ \\
\hline 7. & $\begin{array}{l}\text { I know how to use ICT to improve my students' } \\
\text { learning. }\end{array}$ & $10.71 \%$ & $4.46 \%$ & $84.82 \%$ & $0 \%$ \\
\hline 8. & I have both computer and internet access at my home. & $8.83 \%$ & $0 \%$ & $91.96 \%$ & $0 \%$ \\
\hline \multicolumn{6}{|c|}{ Managing Large Classroom } \\
\hline 9. & $\begin{array}{l}\text { I have to teach many (more than 40) students in my } \\
\text { classroom. }\end{array}$ & $62.25 \%$ & $0 \%$ & $37.5 \%$ & $0 \%$ \\
\hline 10. & $\begin{array}{l}\text { I face a lot of difficulties in teaching such a large } \\
\text { classroom. }\end{array}$ & $58.92 \%$ & $16.96 \%$ & $24.10 \%$ & $0 \%$ \\
\hline 11. & I can easily control my students in the classroom. & $64.28 \%$ & $26.78 \%$ & $8.92 \%$ & $0 \%$ \\
\hline 12. & $\begin{array}{l}\text { Students do not interact with each other in my } \\
\text { classroom. }\end{array}$ & $58.03 \%$ & $26.78 \%$ & $15.17 \%$ & $0 \%$ \\
\hline 13. & $\begin{array}{l}\text { Interaction among students in the classroom disturbs } \\
\text { the other classes nearby. }\end{array}$ & $60.71 \%$ & $17.85 \%$ & $14.28 \%$ & $\mathrm{Uu}$ \\
\hline 14. & My students learn working in groups and pairs. & $50 \%$ & $16.07 \%$ & $22.32 \%$ & $11.60 \%$ \\
\hline 15. & I have difficulties in classroom management. & $56.25 \%$ & $23.21 \%$ & $16.96 \%$ & $3.57 \%$ \\
\hline \multicolumn{6}{|c|}{ Students' Learning Practices } \\
\hline 16. & $\begin{array}{l}\text { Students give much emphasis on solving old questions } \\
\text { (model questions). }\end{array}$ & $42.85 \%$ & $53.57 \%$ & $3.57 \%$ & $0 \%$ \\
\hline 17. & Students only memorize the answer to pass the exam. & $44.64 \%$ & $28.57 \%$ & $25 \%$ & $8.92 \%$ \\
\hline 18. & Students are very serious in their learning. & $17.85 \%$ & $25.89 \%$ & $44.67 \%$ & $11.60 \%$ \\
\hline \multicolumn{6}{|c|}{ Assessing Students, Error correction and Feedback } \\
\hline 19. & $\begin{array}{l}\text { I know how to access/evaluate students' language } \\
\text { performance in a classroom. }\end{array}$ & $73.21 \%$ & $26.78 \%$ & $0 \%$ & $0 \%$ \\
\hline 20. & $\begin{array}{l}\text { I can access/evaluate students' achievement in various } \\
\text { ways. }\end{array}$ & $48.21 \%$ & $43.75 \%$ & $8.03 \%$ & $0 \%$ \\
\hline 21. & $\begin{array}{l}\text { Assessment for learning is an effective tool for } \\
\text { improving teaching and learning. }\end{array}$ & $55.35 \%$ & $14.28 \%$ & $1.78 \%$ & $28.57 \%$ \\
\hline 22. & $\begin{array}{l}\text { I am familiar with common students' mistake and } \\
\text { errors. }\end{array}$ & $50.03 \%$ & $26.78 \%$ & $4.46 \%$ & $10.71 \%$ \\
\hline 23. & $\begin{array}{l}\text { I am confident in correcting students' mistake and } \\
\text { errors. }\end{array}$ & $23.21 \%$ & $41.96 \%$ & $31.25 \%$ & $3.57 \%$ \\
\hline 24. & Making mistake is harmful in language learning. & $26.78 \%$ & $0 \%$ & $42.85 \%$ & $30.35 \%$ \\
\hline 25. & $\begin{array}{l}\text { I ask Instruction Checking Questions and Concept } \\
\text { Checking Questions (ICQ and CCQ) to my students. }\end{array}$ & $7.14 \%$ & $4.46 \%$ & $15.17 \%$ & $73.21 \%$ \\
\hline
\end{tabular}




\begin{tabular}{|c|c|c|c|c|c|}
\hline 26. & $\begin{array}{l}\text { I often practice the activities mentioned in the } \\
\text { statements, } 19,20,23 \text {, and } 24 \text {. }\end{array}$ & $22.32 \%$ & $17.85 \%$ & $49.10 \%$ & $10.71 \%$ \\
\hline \multicolumn{6}{|c|}{ The Medium of Instruction } \\
\hline 27. & $\begin{array}{l}\text { I use students' mother tongue to make my students } \\
\text { understand the text. }\end{array}$ & $71.42 \%$ & $20.53 \%$ & $8.03 \%$ & $0 \%$ \\
\hline 28. & English should only be taught through English. & $60.71 \%$ & $17.85 \%$ & $16.07 \%$ & $5.35 \%$ \\
\hline \multicolumn{6}{|c|}{ Lesson Planning and Time Management } \\
\hline 29. & I am well skilled in lesson planning. & $49.10 \%$ & $33.03 \%$ & $12.5 \%$ & $5.35 \%$ \\
\hline 30. & I have enough time to prepare lesson plan & $18.75 \%$ & $12.5 \%$ & $68.75 \%$ & $0 \%$ \\
\hline 31. & $\begin{array}{l}35-45 \text { minutes' time for per period is inadequate for } \\
\text { teaching English effectively. }\end{array}$ & $62.5 \%$ & $17.85 \%$ & $19.64 \%$ & $0 \%$ \\
\hline \multicolumn{6}{|c|}{ Action Research and Self Reflective Practice } \\
\hline 32. & $\begin{array}{l}\text { Self-reflective practice is quite helpful to improve } \\
\text { teaching and learning. }\end{array}$ & $12.5 \%$ & $14.28 \%$ & $10.71 \%$ & $62.25 \%$ \\
\hline 33. & $\begin{array}{l}\text { I have conducted many action researches to improve } \\
\text { my teaching }\end{array}$ & $16.07 \%$ & $6.25 \%$ & $23.21 \%$ & $54.46 \%$ \\
\hline 34. & $\begin{array}{l}\text { Teachers Professional Development Training (TPDT) } \\
\text { prepares teachers to use research based teaching } \\
\text { strategies based on their own context. }\end{array}$ & $2.67 \%$ & $23.21 \%$ & $55.35 \%$ & $18.75 \%$ \\
\hline 35. & I face many problems while teaching in the classroom. & $66.07 \%$ & $14.28 \%$ & $19.64 \%$ & $0 \%$ \\
\hline 36. & $\begin{array}{l}\text { All of my classroom problems are solved in the } \\
\text { training. }\end{array}$ & $13.39 \%$ & $15.17 \%$ & $71.42 \%$ & $0 \%$ \\
\hline 37. & I share my teaching experiences with my colleagues. & $41.96 \%$ & $33.92 \%$ & $21.42 \%$ & $2.67 \%$ \\
\hline \multicolumn{6}{|c|}{ Teacher Training and Post Training Support } \\
\hline 38. & $\begin{array}{l}\text { I have learnt many teaching skills from the teacher } \\
\text { trainings. }\end{array}$ & $64.28 \%$ & $20.53 \%$ & $15.17 \%$ & $0 \%$ \\
\hline 39. & $\begin{array}{l}\text { It is difficult to implement new methods and techniques } \\
\text { learnt in the training. }\end{array}$ & $62.5 \%$ & $19.96 \%$ & $20.53 \%$ & $0 \%$ \\
\hline 40. & $\begin{array}{l}\text { I want regular mentoring from the experienced teachers } \\
\text { and trainers. }\end{array}$ & $75.89 \%$ & $10.71 \%$ & $12.5 \%$ & $0.89 \%$ \\
\hline 41. & $\begin{array}{l}\text { Feedback from experienced teachers plays an important } \\
\text { role in successful language teaching and learning. }\end{array}$ & $75 \%$ & $10.71 \%$ & $13.39 \%$ & $0.89 \%$ \\
\hline
\end{tabular}

